\title{
Cytology and molecular study for GSTP1 effect on asthma Iraqi patients
}

\author{
Israa Hussein Hamzah ${ }^{1 \dagger}$, Farha A. Ali Shafi ${ }^{1 \dagger}$, Sahar A. H. Al Sharqi ${ }^{1{ }^{* \dagger}}$ and Suaad Almas Brakhas ${ }^{2+}$
}

\begin{abstract}
Background: GST belongs to a super family of phase II detoxification enzyme and it plays an important role in preventing the damage that may occur due to reactive water-soluble compounds generated by the association of reactive intermediates with glutathione.

Method: In the present study, we analyzed the frequencies of GSTP1 polymorphism among the Iraqi population using PCR-RFLP technique. Fifty samples from bronchial asthma patients and fifty samples from control cases were subjected to conventional PCR and Restriction Fragment Length Polymorphism (RFLP) to detect GSTP1 genotype and measured different parameters together such as IgE, eosinophilic count, WBC, and so forth. Some of the cases were made to undergo sequence analysis and enrolled in NCBI GenBank with accession number (MG657249-MG657258). The GSTP1 polymorphism was determined using PCR and the resultant 176-bp fragment was subjected to RFLP and digested with BsamA1 to recognize the $\mathrm{A}-\mathrm{G}$ transition at nucleotide.
\end{abstract}

Results: Homozygotes for lle105 encoding allele resulted in 176-bp fragment found in 62\% andVal 105 encoding allele had two fragments of 91 and 85 bp in PCR was found in 4\% of asthmatic patients. On the other hand, heterozygotes resulted in three fragments of 176, 91 and 85 bp seen in 34\% of patients.

Conclusion: To the best of the researcher's knowledge, this is the first-of-its-kind report with regards to the role played by GSTP1 polymorphism in bronchial asthma among the Iraqi patients. Though the study outcomes do not support the large role played by GSTP1 gene polymorphism in the evolution of bronchial asthma disorder, future researchers are suggested to investigate more features for many promising results.

Keywords: Asthma, GSTP1, Polymorphism, BsmA1, RFLP, Iraq

\section{Introduction}

Asthma occurs as a result of continuous irritation of the accomplishing areas in lungs (in particular, the bronchi and the bronchioles) which subsequently results in expanded contractibility of the encompassing smooth muscle groups [1-5]. Asthma has an effect on people irrespective of their age though it most affects during the early stage of life. It has a high rate of occurrence across the world in the past 25 years [2]. The pathogenesis and etiology of asthma are very complex and not completely

\footnotetext{
*Correspondence: szsh@uomustansiriyah.edu.iq

${ }^{\dagger}$ Israa Hussein Hamzah, Farha A. Ali Shafi, Sahar A. H. Al Sharqi and Suaad

Almas Brakhas contributed equally in the research work

1 Biology Department, College of Science, Mustansiriyah University,

Baghdad, Iraq

Full list of author information is available at the end of the article
}

understood. It is a far prediction that asthma is caused by a combination of genetic and environmental factors which includes exposure to air pollutants and allergens. Asthma may occur due to other capacity triggers such as medicinal drugs like aspirin and beta blockers [3-6].

Glutathione S-transferase P (GST), encoded by the GSTP1 gene, is a human enzyme that predominantly shields the human body against antioxidants and play an important role in the regulation of inflammatory responses. GST usually conjugate glutathione with electrophilic materials that are capable of generating free radicals as a result of detoxification [7-9]. The GSTP1 gene is positioned in the chromosome 11q13 whereas the polymorphisms of GSTP1 gene act as danger elements for asthma disease especially four alleles such as GSTP1A

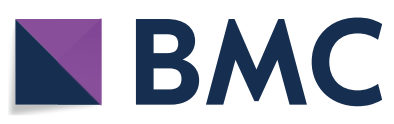

(c) The Author(s) 2019. This article is distributed under the terms of the Creative Commons Attribution 4.0 International License (http://creativecommons.org/licenses/by/4.0/), which permits unrestricted use, distribution, and reproduction in any medium, provided you give appropriate credit to the original author(s) and the source, provide a link to the Creative Commons license, and indicate if changes were made. The Creative Commons Public Domain Dedication waiver (http://creativecommons.org/ publicdomain/zero/1.0/) applies to the data made available in this article, unless otherwise stated. 
(Ile105-Ala114) GSTP1B (Val105-Ala114), GSTP1C (Val105-Val114) and GSTP1D (Ile105-Val114) [9-11].

There is no or ignorable data on gene polymorphisms of GSTP1 and their role among asthma patients from Iraqi providence. Therefore we intend to design this work with speculation that GSTP1 polymorphism has a role to play in asthma related phenotype. This study also discovers any association of blood indices with asthma patients.

\section{Materials and methods}

This study was designed and approved by the Institutional Ethical Committee. According to university hospital protocol, bronchial asthma was diagnosed primarily based on medical signs, symptoms, and response to remedy as per the Global Initiative on Asthma classification scheme $[12,13]$. The study was done among 100 Iraqi individual consisting 50 clinically-diagnosed asthma patients and 50 healthy controls from the Allergy Specialized Center, Baghdad/Resafa. Their age range was $16-65$ years. Subsequent elaborate data was obtainedwhich included age, gender, private history of allergies, seasonal coryza, eczema, allergic conjunctivitis and total serum (IgE level $>100 \mathrm{IU} / \mathrm{ml}$ ) measured by Enzyme-Linked-Immunosorbent Serological Assay (ELISA) whereas the White Blood Cells (WBC), HB, ESRand eosinophil count were calculated by victimization machine-driven count system.

\section{Sample collection}

Five $\mathrm{ml}$ of blood sample was collected from all the study participants including control by vein puncture using disposable syringes. The blood sample was aliquoted into two tubes of which the first was to obtain a clot which was then separated by centrifugation at $3000 \mathrm{rpm}$ for $10 \mathrm{~min}$ to separate serum. This was used for IgE level measurement assay through ELISA. The second aliquot of $2 \mathrm{ml}$ was kept in EDTA tube, and stored in the freezer $\left(-20^{\circ} \mathrm{C}\right)$ in order to extract DNA. The total IgE kit was used to estimate the IgE class antibodies level in the serum of patients and control (Total IgE ELISA Kit Quantitative Assay for Total IgE Antibodies, Omega diagnostic).

\section{Molecular analysis}

For PCR and RFLP analysis, the DNA was extracted from whole blood using Wizard Genomic DNA purification kit (Promega) according to the manufacturer's instructions. The GSTP1 polymorphism was by PCR-based Restriction Fragment Length Polymorphism (PCR-RFLP) according to a published protocol [14]. The sequence of primer that targeted GSTP1 is as follows F: ACCCCAGGG CTCTATGGGAA; R: TGAGGGCACAAGAAGCCC CT. The extracted DNA was used as a DNA template in a $25 \mu \mathrm{l}$ solution containing $12.5 \mu \mathrm{l}$ of $\mathrm{Tag}^{\circledR}$ Green Master Mix $(2 \times)$ (Promega, USA), $1.5 \mu \mathrm{l}$ each from forward and reverse primers, $5 \mu \mathrm{l}$ of DNA template and $4.5 \mu \mathrm{l}$ of nuclease-free water. The PCR condition was as follows: an initial denaturation step at $95{ }^{\circ} \mathrm{C}$ for 5 min followed by 30 repetitive cycles of denaturation at $94{ }^{\circ} \mathrm{C}$ for the $30 \mathrm{~s}$, annealing at $60{ }^{\circ} \mathrm{C}$ for $30 \mathrm{~s}$ and extension at $72{ }^{\circ} \mathrm{C}$ for $30 \mathrm{~s}$. A final extension at $72{ }^{\circ} \mathrm{C}$ for $10 \mathrm{~min}$ was also included. After that, the PCR products were purified with the commercially available kit (PCR Clean-up Kit, USA) to remove the excess dNTPs, primers, ethidium bromide, and enzymes.

The purified products of PCR were digested in $20 \mu \mathrm{l}$ quantity for $2 \mathrm{~h}$ at $55{ }^{\circ} \mathrm{C}$ with $2.5 \mathrm{BsmA} 1$ (BioLab). The digested products were then checked in $3 \%$ agarose gel stained with ethidium bromide. The presence of $176 \mathrm{bp}$ fragment indicated the wild-kind genotype (Ile/Ile) while the presence of 85 and $91 \mathrm{bp}$ fragments indicated the homozygous polymorphic genotype (Val/Val). The heterozygote turned into records in the presence of all the three fragments. Negative and positive controls were protected in all reactions to ensure that the samples are not contaminated during the procedures.

The sequences of all amplified DNA of patients blood samples retrieved from the DNA sequencer were then submitted to three international bioinformatics websites such as NCBI gene bank (National Center for Biotechnology Information), DNA data bank of Japan (DDBJ) and European bioinformatics institute (EMBL) with same title of this article along with a unique ID number (Accession number) (MG657249-MG657258). The statistical analysis was performed using the SPSS software program with P-values $<0.05$ as the significance. The descriptive records were expressed as the mean \pm standard deviation (SD)[15].

\section{Results}

The individuals were recognized whether they are asthmatic or non-asthmatic on the basis of allergic or respiration signs, pores, skin allergic reaction assessments, $\operatorname{IgE}$ tiers, lung feature indices and other different signs such as wheezing, cough, dyspnea, and/or chest tightness. Among the 100 subjects who participated in this study, $21(42 \%)$ were male asthmatics and $29(58 \%)$ were female asthmatics, while the Male-To-Female ratio inside the control group got changed into 23 (46\%) and 27 (54\%) respectively (Table 1).

The mean age of the considered cases was $44.10 \pm 11.744$ while the mean age of females was $43.58 \pm 12.347$ and the overall age range was $16-65$ years (Table 2). The private characteristics of the studied instances and controls are summarized in Table 3. Eosinophilic count, WBC, $\mathrm{HB}$, and ESR confirmed that there is 
Table 1 The classify of gender for the studied cases and controls

\begin{tabular}{|c|c|c|c|c|c|}
\hline & \multicolumn{5}{|c|}{ Gender distribution } \\
\hline & $\begin{array}{l}\text { Frequency } \\
\text { (n) }\end{array}$ & Percent & $\begin{array}{l}\text { Valid } \\
\text { percent }\end{array}$ & $\begin{array}{l}\text { Cumulative } \\
\text { percent }\end{array}$ & $\begin{array}{l}\text { Significance } \\
\text { (P) }\end{array}$ \\
\hline \multicolumn{6}{|l|}{ Cases } \\
\hline Male & 21 & 42 & 42 & 42 & 0.0572 \\
\hline Female & 29 & 58 & 58 & 100 & \\
\hline Total & 50 & 100 & 100 & & \\
\hline \multicolumn{6}{|l|}{ Control } \\
\hline Male & 23 & 46 & 46 & 46 & 0.0572 \\
\hline Female & 27 & 54 & 54 & 100 & \\
\hline Total & 50 & 100 & 100 & & \\
\hline
\end{tabular}

Table 2 The personal characteristics according age and gender

\begin{tabular}{|c|c|c|c|}
\hline $\begin{array}{l}\text { Personal } \\
\text { characteristics }\end{array}$ & Cases $(n=50)$ & Control $(n=50)$ & Significance $(P)$ \\
\hline Sex (male) & $42 \%$ & $46 \%$ & 0.0258 \\
\hline Sex (female) & $58 \%$ & $54 \%$ & \\
\hline $\begin{array}{l}\text { Age (years) (mini- } \\
\text { mum-maxi- } \\
\text { mum) }\end{array}$ & $17-62$ & $16-65$ & 0.0572 \\
\hline Range & 45 & 49 & \\
\hline Mean \pm SD & $44.10 \pm 11.744$ & $43.58 \pm 12.347$ & \\
\hline
\end{tabular}

no statistical significance of the distinction between the cases and the controls while IgE and the history of individual asthmatic patients showed a significant difference.

The PCR amplification showed a band of $176 \mathrm{bp}$ in all the samples (Fig. 1). The resultant 176-bp fragment digested with BsamA1 which identify the A-G transition (Fig. 2), showed an undigested 176-bp fragment

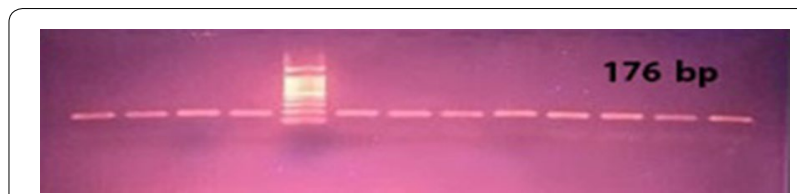

Fig. 1 The product of PCR

for homozygotes Ile105-encoding allele (GSTP1 Ile105/ Ile105 genotype); two fragments of 91 and 85 bp was seen for homozygous Val105-encoding individuals (GSTP1Val105/Val105 genotype) resulted. The PCR products from heterozygotes (GSTP1 Ile105/Val105 genotype) comprised 176, 91, and 85 bp fragments (Fig. 3). Homozygous genotype (Ile/Ile) was detected in $62 \%$ of asthmatic patients and in $68 \%$ of the controls whereas the $\mathrm{Val} / \mathrm{Val}$ genotype becomes determined with just $4 \%$ of patients and $2 \%$ of controls. Further, the heterozygous genotype Ile/Val was identified in 34\% of sufferers and $30 \%$ of controls. Overall, there was no significant difference among all the groups $(\mathrm{P} \leq 0.01)$ (Figs. 4, 5).

There had been no significance differences between cases with unique GSTP1 genotypes with regards to WBC count, eosinophilic count, HB count, and ESR ratio (Table 4). With regards to atopy, the study iterated the study stratification i.e., first, the people with $\operatorname{IgE}>100$ (40 cases) and people with IgE $<100$ (60 cases) while for the second, those with a history of allergy (21 cases) (42\%) and people with out such history (29 cases) (58\%). Table 5 suggests GSTP1 genotype frequencies when it comes to IgE level. The frequencies for GSTP1 genotypes in subjects with IgE levels $<100$ IU/ $\mathrm{ml}$ and $>100 \mathrm{IU} / \mathrm{ml}$ had been no longer significantly different $(P=0.056)$. Figure 5 suggests the affiliation of GSTP1 genotypes with a family history of bronchial

Table 3 The laboratory and pulmonary function tests results of the studied samples with bronchial asthma according to GSTP1 genotyping

\begin{tabular}{|c|c|c|c|c|c|}
\hline \multirow{2}{*}{$\begin{array}{l}\text { Laboratory/pulmonary function } \\
\text { results }\end{array}$} & \multicolumn{2}{|c|}{ Patients sample } & \multicolumn{2}{|c|}{ Control } & \multirow[t]{2}{*}{ Significant $(P)$} \\
\hline & Mean & SD & Mean & SD & \\
\hline WBC $10^{9} / \mathrm{I}$ & 9.218 & \pm 3.10350 & 8.76 & \pm 2.49816 & 0.05 \\
\hline $\mathrm{HB}$ & 12.3 & \pm 1.52610 & 12.5 & \pm 1.66831 & 0.05 \\
\hline ESR & 24.26 & \pm 15.10347 & 20.16 & \pm 8.73034 & 0.05 \\
\hline Eosinophil & 5.06 & \pm 2.14200 & 4.48 & \pm 1.432 & 0.05 \\
\hline $\lg E$ & 311.39 & \pm 135.98607 & 68.23 & \pm 30.16270 & 0.05 \\
\hline \multicolumn{6}{|l|}{ Family history } \\
\hline Yes & 44 & NA & 2 & NA & \\
\hline No & 6 & NA & 48 & NA & \\
\hline
\end{tabular}




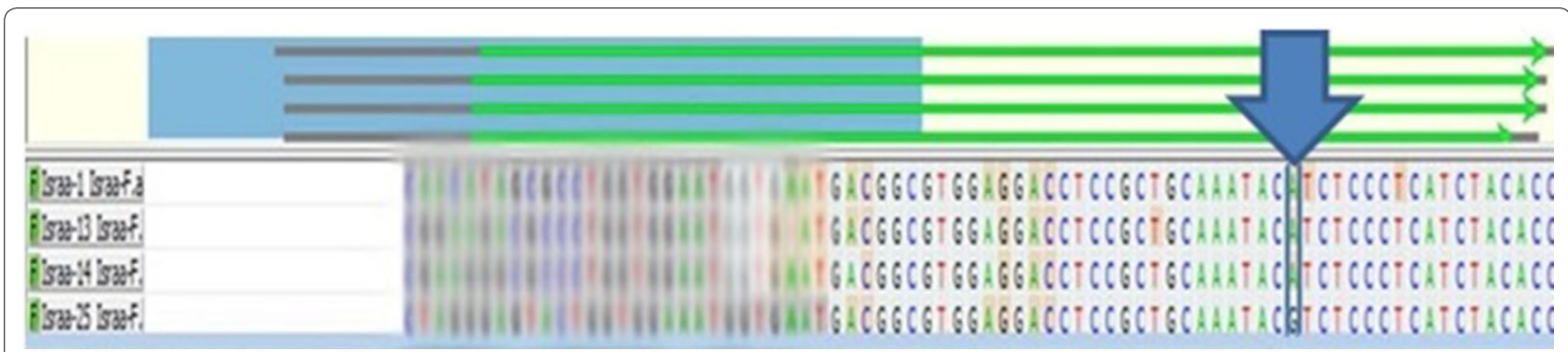

Fig. 2 The analysis of the $A-G$ transition at nucleotide

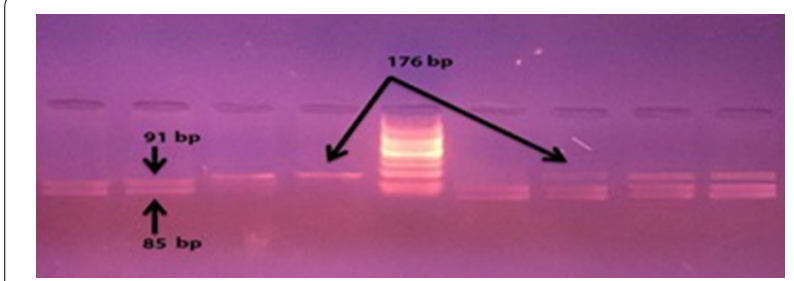

Fig. 3 The results of REFLP

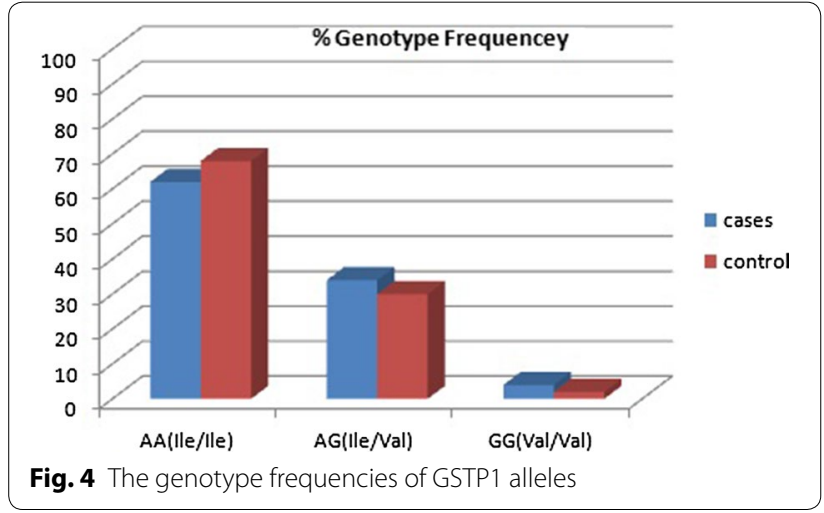

asthma. No distinct associations were found among the GSTP1 genotypes and atopic status.

\section{Discussion}

Asthma is an intricate, multifactorial disease with appearance from genetic predisposition, immunological responses, and intermediate of environmental elements. It recollects as a foremost public health challenge that affects 100-150 million human beings across the globe [16]. In the current study, the incidence of bronchial asthma is higher among females than males in alignment with the earlier research [17]. The reasons for gender difference is unknown but there has been a connection with immunological and hormonal factors, and/or to

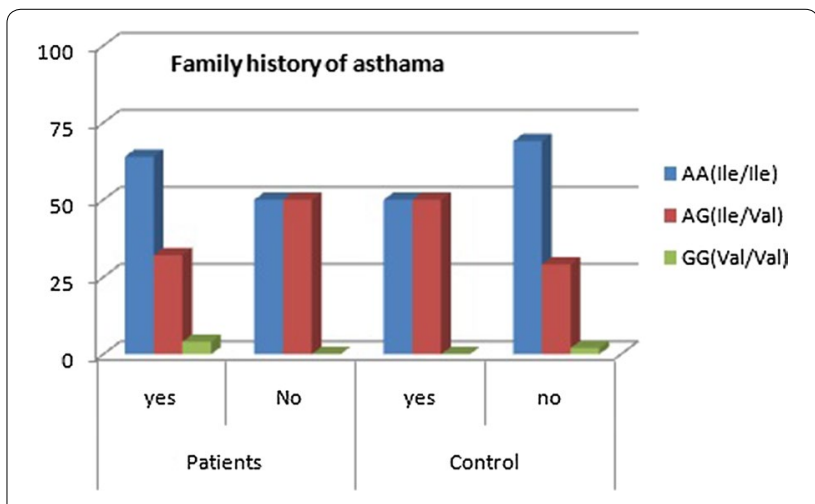

Fig. 5 The family history with genotype frequencies

variations in gender-specific responses to vocational and environmental exposures [18]. Genetic polymorphisms are also encouraged through gender. Immunoglobulin E (IgE) titer and asthma had been related to Single Nucleotide Polymorphisms (SNPs) in Thymic Stromal Lympho poietin (TSLP) [19].

Many research articles demonstrated the association of genes with hypersensitive reaction/asthma [20]. Ober et al. [21] cited the association of genes with bronchial asthma or atopy in more than 10 research articles. Most genetic studies conducted on asthma concentrated on genes in the chromosomes $11 \mathrm{q}$ and $5 \mathrm{q}$ and their association with the key bronchial asthmaassociated phenotypes of Bronchial Hyper Responsiveness (BHR) and atopy. Although bronchial asthma is characterized through airway infection, oxidative stress is a crucial issue in this regard since few research inferred that there are genes involved in opposition to this action. GST gene polymorphisms acknowledged risk factors for some environmentally-associated diseases. Several population studies connected genetic variation in human GSTP1 with greater susceptibility to asthma and the severity of signs. An association study was designed in the literature to understand 
Table 4 Laboratory blood cell counts of study samples

\begin{tabular}{|c|c|c|c|c|}
\hline \multirow[t]{2}{*}{ Laboratory results } & \multicolumn{3}{|l|}{ GSTP1 genotype } & \multirow[t]{2}{*}{ Kruskal-Wallis test $(P)$} \\
\hline & Ile/Ile (65) & Ile/Val (32) & Val/Val (3) & \\
\hline \multicolumn{5}{|l|}{ WBC } \\
\hline Min-mix & $4.50-18.40$ & $4.50-18.40$ & $8.70-18.40$ & $1.464(0.0586)$ \\
\hline Mean \pm SD & $8.7538 \pm 2.65389$ & $9.6094 \pm 3.55213$ & $12.3667 \pm 5.26530$ & \\
\hline \multicolumn{5}{|l|}{$\mathrm{Hb}$} \\
\hline Min-mix & $9.40-15.20$ & $10.40-15.20$ & $11.50-15.20$ & 0.843 \\
\hline Mean $\pm S D$ & $12.0369 \pm 1.4726$ & $12.6219 \pm 1.2868$ & $13.9667 \pm 2.13620$ & -0.058 \\
\hline \multicolumn{5}{|l|}{ ESR } \\
\hline Min-mix & $5.00-63.00$ & $5.00-63.00$ & $13.00-63.00$ & $0.100(0.0 .586)$ \\
\hline Mean \pm SD & $22.6154 \pm 14.10307$ & $25.9688 \pm 15.19228$ & $31.0000 \pm 27.78489$ & \\
\hline \multicolumn{5}{|l|}{ Eosinophil } \\
\hline Min-mix & $2.00-9.00$ & $2.00-9.00$ & $4.00-6.00$ & $0.629(0.0 .586)$ \\
\hline Mean $\pm S D$ & $4.9692 \pm 2.08394$ & $5.4688 \pm 2.16995$ & $4.6667 \pm 1.15470$ & \\
\hline
\end{tabular}

Table 5 IgE level according to genotype distributions for GSTP1 gene polymorphism in sample studies with asthma

\begin{tabular}{|c|c|c|c|c|}
\hline \multicolumn{4}{|c|}{ IgE concentration with genotype frequencies } & \multirow[t]{3}{*}{ Significance } \\
\hline & \multicolumn{3}{|c|}{ Genotype frequencies } & \\
\hline & AA (Ile/Ile) & AG (lle/Val) & GG (Val/Val) & \\
\hline Less 100 & 30 & 9 & 1 & 0.056 \\
\hline More 100 & 39 & 19 & 2 & \\
\hline
\end{tabular}

whether an allelic variation on the glutathione-S-transferase GSTP1 locus, affects the expression of BHR and atopy phenotypes in bronchial asthma. The enzyme encoded by GSTP1 makes use of a ramification of lipid and DNA products of oxidative pressure whereas the polymorphic editions of this gene are related with the enzyme's altered catalytic function $[9,16]$.

As it evident from the literature that a number of study on GSTP1 polymorphism and its relation with a different aspect of the respiratory function of human is done. Mutation on GSTP1 does not have only direct effect to asthma symptoms but two-way gene-air pollution interaction between GSTP1 has the risk of childhood asthma. The study suggests that interaction between GSTP1 and PM10 may alter the susceptibility to childhood asthma and buffers the harmful effects of air pollution [22]. A significant interaction of GSTP1 SNPs, to atopy, and ETS exposure have been identified in a cohort study [23]. Reports from Tunisian children demonstrated that polymorphisms of GST genes were associated with asthma and atopy and its genotypes were considered useful in future treatment optimization in the cases of increasing risk profile of asthma [24]. Allelic frequencies of SNPs of GSTP1 was found statistically significantly different in the asthmatic group compared with the controls and also a relationship between allele frequencies and different clinical phenotypes such as atopia nocturnal dyspnea, and steroid dependency was observed in asthmatic patients suggesting GSTP1 role in severeness of airway dysfunction [25]. As it is now well indicated in different studies that GSTP1 genotypes and polymorphism have important roles in asthma pathogenesis. It is also possible that intermediate metabolites, which are not metabolized or not excreted due to malfunction of GSTP1 may damage cells contributing to the pathogenesis of asthma [26].

The current study determined that there is a dramatic decrease in the frequency of GSTP1 Val105/Val105 in asthmatic and control subjects. The presence of genotypes GSTP1 Ile105/Ile105 and Il105/Val105 were found in $62 \%$ of the sufferers and $68 \%$ of the controls as well as in $34 \%$ of patients and $30 \%$ of controls respectively with no significant difference among the groups $(\mathrm{P} \leq 0.01)$. According to Table 5 , after correction for allele version with age, gender and different parameters that were consistent with laboratory outcomes of character traits, the frequency of GSTP1 Val105/Val105 correlated with increasing WBC (8.70-18.40) when compared with different allele variations that had less number of WBCs (Table 5). The increasing values of $\mathrm{HB}, \mathrm{ESR}$ and $\operatorname{IgE}<100$ were correlating with decreasing values of eosinophil rapprochement with other allele contrast (Table 5).

So, the genotype distributions of GSTP1 gene polymorphism between the asthma subjects and controls showed no significant difference $(\mathrm{P}=0.056)$. In most human beings, the major GSTP1 alleles are Ile105 (frequency $>50 \%$ ). Epidemiological studies advised that due 
to individual differences within the expression of allelic variations of GSTP1 gene, they may be differences in slobber to numerous chemical substances and differences in capability to metabolize these retailers [27]. The higher IgE level, within the control group, can be explained through the better occurrence of parasitic infection and affected the patients from the region under study [28]. Some of the genes related to bronchial asthma have been replicated in one-of-its-kind research, but a maximum of them are not investigated further. This may be due to the fact that different investigations were conducted among different populations with exclusive genetic heritage, age, time, gender and environmental features.

\section{Conclusion}

To the best of the researcher's knowledge, this is the first-of-its-kind report with regards to the role played by GSTP1 polymorphisms in bronchial asthma among Iraqi patients. The findings of the current study no longer assist in the critical function of GSTP1 gene polymorphism within the evolution of asthma disorder. So a much wider and in-depth investigation of genetic-environmental interplay is required. Therefore, future studies ought to be executed in greater realistic settings with much environmental exposure so as to reach an authenticated starting point for the detection and discussion of gene-environment interplay and other genes concerned with the antioxidant pathway.

\section{Authors' contributions}

IHFS collected data and analysed it; SAHAS and SAB helps in data analyses and manuscript preparation. All authors read and approved the final manuscript.

\section{Author details}

${ }^{1}$ Biology Department, College of Science, Mustansiriyah University, Baghdad, Iraq. ${ }^{2}$ Allergy Specialized Center, Baghdad/Resafa, Iraq.

\section{Acknowledgements}

The authors would really like to thank all the patients who participated in this study; the authors additionally acknowledge the infrastructure and guide of the Biology Department/College of Science/Al-Mustansiriyah University.

\section{Competing interests}

The authors declare that they have no competing interests.

\section{Ethics approval and consent to participate}

All procedures performed in studies involving human participants were in accordance with the ethical standards of the institutional and/or national research committee and with the 1964 Helsinki declaration and its later amendments or comparable ethical standards.

\section{Funding information}

This study did not receive any precise supply from funding organizations in the public, industrial, or no longer-for-income sectors.

\section{Informed consent (In case humans are involved)}

Informed consent was obtained from all individual participants included in the study.

\section{Publisher's Note}

Springer Nature remains neutral with regard to jurisdictional claims in published maps and institutional affiliations.

Received: 20 October 2018 Accepted: 4 February 2019

Published online: 05 March 2019

\section{References}

1. Minelli C, Granell R, Newson R, Rose-Zerilli MJ, Torrent M, Ring SM, Holloway JW, Shaheen SO, Henderson JA. Glutathione-S-transferase genes and asthma phenotypes: a Human Genome Epidemiology (HuGE) systematic review and meta-analysis including unpublished data. Int J Epidemiol. 2009;39(2):539-62.

2. Palmer LJ, Cookson WO. Genomic approaches to understanding asthma. Genome Res. 2000;10(9):1280-7.

3. Maddox L, Schwartz DA. The pathophysiology of asthma. Ann Rev Med. 2002:53(1):477-98.

4. Sengler C, Lau S, Wahn U, Nickel R. Interactions between genes and environmental factors in asthma and atopy: new developments. Respir Res. 2001;3(1):7.

5. Sohn SW, Jung JW, Lee SY, Kang HR, Park HW, Min KU, Cho SH. Expression pattern of GSTP1 and GSTA1 in the pathogenesis of asthma. Exp Lung Res. 2013;39(4-5):173-81.

6. Spiteri MA, Bianco A, Strange RC, Fryer AA. Polymorphisms at the glutathione S-transferase, GSTP1 locus: a novel mechanism for susceptibility and development of atopic airway inflammation. Allergy. 2000;55:15-20.

7. Rahman I, MacNee W. Oxidative stress and regulation of glutathione in lung inflammation. Eur Respir J. 2000;16(3):534-54.

8. Sharma A, Pandey A, Sharma S, Chatterjee I, Mehrotra R, Sehgal A, Sharma JK. Genetic polymorphism of glutathione S-transferase P1 (GSTP1) in Delhi population and comparison with other global populations. Meta Gene. 2014;31(2):134-42.

9. Fryer AA, Bianco A, Hepple M, Jones PW, Strange RC, Spiteri MA. Polymorphism at the glutathione S-transferase GSTP1 locus: a new marker for bronchial hyper responsiveness and asthma. Am J Respir Crit Care Med. 2000;161(5):1437-42.

10. Zhao E, Zhao Y. Lack of association between GSTP1 lle105Val polymorphism and coronary heart disease risk: a meta-analysis. Int J Clin Exp Med. 2015:8(10):18488.

11. Kim EJ, Kwon JW, Lim YM, Yoon D, Seo JH, Chang WS, Kim HY, Park JW, Cho SH, Hong SJ, Lee JS. Assessment of total/specific lgE levels against 7 inhalant allergens in children aged 3 to 6 years in Seoul, Korea. Allergy Asthma Immunol Res. 2013;5(3):162-9.

12. Scottish IG. British guideline on the management of asthma. Thorax. 2003;58:11.

13. Bisgaard H, Zielen S, Garcia-Garcia ML, Johnston SL, Gilles L, Menten J, Tozzi CA, Polos P. Montelukast reduces asthma exacerbations in 2-to 5-year-old children with intermittent asthma. Am J Respir Crit Care Med. 2005;171(4):315-22.

14. Harries LW, Stubbins MJ, Forman D, Howard GC, Wolf CR. Identification of genetic polymorphisms at the glutathione S-transferase Pi locus and association with susceptibility to bladder, testicular and prostate cancer. Carcinogenesis. 1997;18(4):641-4.

15. Sanger F, Nicklen $S$, Coulson AR. DNA sequencing with chain-terminating inhibitors. Proc Natl Acad Sci. 1977;74(12):5463-7.

16. Mahmoud MI, Kassem HS, Wahab NH, Saad AA, Moez P. The association between glutathione S-transferase P1 polymorphisms and asthma in Egyptians. Alexandria J Med. 2011;47(2):105-15.

17. Zein JG, Erzurum SC. Asthma is different in women. Curr Allergy Asthma Rep. 2015;15(6):28.

18. Vink NM, Postma DS, Schouten JP, Rosmalen JG, Boezen HM. Gender differences in asthma development and remission during transition through puberty: the TRacking Adolescents'Individual Lives Survey (TRAILS) study. J Allergy Clin Immunol. 2010;126(3):498-504.

19. Hunninghake GM, Soto-Quirós ME, Avila L, Kim HP, Lasky-Su J, Rafaels N, Ruczinski I, Beaty TH, Mathias RA, Barnes KC, Wilk JB. TSLP polymorphisms 
are associated with asthma in a sex-specific fashion. Allergy 2010;65(12):1566-75.

20. Holloway JW, Yang IA, Holgate ST. Genetics of allergic disease. J Allergy Clin Immunol. 2010;125(2):S81-94.

21. Ober C, Hoffjan S. Asthma genetics 2006: the long and winding road to gene discovery. Genes Immun. 2006;7(2):95.

22. Su MW, Tsai CH, Tung KY, Hwang BF, Liang PH, Chiang BL, Yang YH, Lee YL. GSTP 1 is a hub gene for gene-air pollution interactions on childhood asthma. Allergy. 2013:68(12):1614-7.

23. Schultz EN, Devadason SG, Khoo SK, Zhang G, Bizzintino JA, Martin AC, Goldblatt J, Laing IA, Le Souëf PN, Hayden CM. The role of GSTP1 polymorphisms and tobacco smoke exposure in children with acute asthma. J Asthma. 2010;47(9):1049-56.

24. Hanene $\mathrm{C}$, Jihene L, Jamel A, Kamel H, Agnes H. Association of GST genes polymorphisms with asthma in Tunisian children. Mediat Inflam. 2007:2007:19564.
25. Kaymak C, Aygun Kocabas N, Aydın N, Oztuna D, Karakaya AE. The relationship between glutathione S-transferase-P1 and beta-2 adrenoreceptor genotypes with asthmatic patients in the turkish population. Genetic Test Mol Biomarkers. 2016;20(9):522-8.

26. Tamer L, Çalikoğlu M, Ates NA, Yildirim H, Ercan B, Saritas E, ÜnlÜ A, Atik U. Glutathione-S-transferase gene polymorphisms (GSTT1, GSTM1, GSTP1) as increased risk factors for asthma. Respirology. 2004;9(4):493-8.

27. Goodrich JM, Basu N. Variants of glutathione S-transferase pi 1 exhibit differential enzymatic activity and inhibition by heavy metals. Toxicol In Vitro. 2012;26(4):630-5.

28. Anupama N, Sharma MV, Nagaraja HS, Bhat MR. The serum immunoglobulin E level reflects the severity of bronchial asthma. Thai J Physiol Sci. 2005;18:35-40.
Ready to submit your research? Choose BMC and benefit from:

- fast, convenient online submission

- thorough peer review by experienced researchers in your field

- rapid publication on acceptance

- support for research data, including large and complex data types

- gold Open Access which fosters wider collaboration and increased citations

- maximum visibility for your research: over $100 \mathrm{M}$ website views per year

At BMC, research is always in progress.

Learn more biomedcentral.com/submissions 